\title{
Influences Of Brand Experience, Brand Trust, And Brand Love Toward Purchase Intention By Word Of Mouth And Brand Loyalty As Intervening Variables In Fashion Branded In East Surabaya
}

\author{
Titi Murtiningsih \\ Managemental Master Study Program of Economical and Business, \\ Faculty of University of 17 Agustus 1945 Surabaya \\ Mohammad Sihab Ridwan \\ Managemental Master Study Program of Economical and Business, \\ Faculty of University of 17 Agustus 1945 Surabaya \\ Wiwik Retnaningsih \\ Managemental Master Study Program of Economical and Business, \\ Faculty of University of 17 Agustus 1945 Surabaya
}

\begin{abstract}
The fashion industrial growth is seen from many and many retail shops and modern shopping centers that emerge, especially Surabaya city. Brand has special emotional bond created between consumers and company, so consumer love toward some brand will give positive impacts. This research aims to know influences of brand experience, brand trust, and brand love toward purchase intention by word of mouth and brand loyalty as intervening variables in fashion branded in East Surabaya. The approach used is quantitative method by causal research type. The research samples are fashion branded users of Nike brand in East Surabaya as 190 respondents. The instruments used are questionnaires by using Likert scale. The analysis technique chosen for analyzing data and testing hypothesis in this research The Structural Equation Model (SEM). The research results show that Brand Experience and Brand Trust influence toward Word of Mouth in Fashion Branded in East Surabaya. Brand Experience does not influence significantly but it has positive influence directions toward Purchase Intention in Fashion Branded in East Surabaya. Brand Experience influences toward Brand Loyalty in Fashion Branded in East Surabaya. Brand Trust influences toward Purchase Intention in Fashion Branded in East Surabaya. Brand Trust does not influence significantly but it has positive influences toward Brand Loyalty in Fashion Branded in East Surabaya. Brand Love does not influence significantly but it has positive influence directions toward Word of Mouth in Fashion Branded in East Surabaya. Brand Love does not influence significantly but it has positive influence directions toward Purchase Intention in Fashion Branded in East Surabaya. Brand Love does not influence toward Brand Loyalty. Word of Mouth and Brand Loyalty influence toward Purchase Intention in Fashion Branded in East Surabaya.
\end{abstract}

Keywords: Brand Experience,Brand Trust,Brand Love,Purvhase Intention,Word of Mouth,Brand Loyalty

\section{INTRODUCTION}

The era is more and more advanced and followed by economical globalization that grows rapidly. One of retail industries that experience quite significant development is retail industry in fashion field. The fashion industrial growths are seen very clearly from many and many retail shops and modern shopping centers that emerge, especially Surabaya city. According to Indonesian Shopping Center Manager Association Chief (APPBI) East Java, international fashion brand occupancies in total Surabaya malls had achieved $60 \%$ and almost all main 
shops in malls have quite-wide places such as H\&M, Pull and Bear, Zara, Stradivarius, LC Waikiki and so on and also opened the first Uniqlo fashion retails in Surabaya (Jawa Pos, 2017). according to Ridwan (2016) The development of company should consider the enviroment (society). (Ridwan,2016).

The total trademarks domestically and abroadly that enliven retail industries in the fashion field are accompanied by the increasing and increasing competitive competitions, because consumers are faced and faced by many brands, so brand trust can also give contributions in purchase intention increase, as Wang \& Lee, (2016) the research results found that brand trust has also significant influences toward purchase intention. Goh Chin Wei (2014) showed that really love has good or positive relations toward mouth communications. According to Ridwan (2019); Ridwan and Marti (2012) and Ridwan (2017), the organizational performance is also influenced by the contect of organization such as organizational culture and decision types.

Based on the problems explained above, so this research aims to analyze and interpret influences of brand experience, brand trust, and brand love toward purchase intention by word of mouth and brand loyalty as intervening variables in fashion branded in East Surabaya.

\section{Brand Experience}

\section{THEORETICAL FRAMEWORK}

Brand experience is personal informational source that can be used for forming future decision basis, such as repurchase intention (Chinomona, 2013).

Brand experience is begun when consumers are seeking products, purchasing, and when accepting services and when consuming products. Brand experience can be felt directly and indirectly when consumers are seeing advertisement or also when marketers communicate the products through website (Chinomona, 2013).

\section{Brand Trust}

Trust is general hope that can be maintained by individual, in which words from one party to other parties can be trusted. Trust is important variable for developing long-term relations for the related parties.

Opportunistical ones can be avoided when trust is formed and has positive hopes, Robbins and Judge (2012)

\section{Brand Love}

Brand Love can be meant as emotional bond level full of consumer satisfaction passions for having certain brand (Carrol and Ahuvia, 2006). Furthermore, Carrol and Ahuvia (2006) explained that if consumers have used or felt full satisfaction level, it will influence consumer loves toward brand, so consumers will be more loyal toward brand and they give good words about the brand to many parties they want. The value is called as brand love.

\section{Word of Mouth}

Word of Mouth can happen when consumers talk about brand, product qualities and the services that have been used by them. Kotler and Armstrong (2012) mentioned reference intention is individual communication about the products between consumers and close other people. WOM can be said as very effective promotion form. 


\section{Brand Loyalty}

According to Andriani and Bunga (2017), brand loyalty is happy attitude toward brand or product conducted in purchasing more than one time or frequently toward the brand in longterm. When consumer is loyal toward the brand, consumer does not consider other products or brands for purchased except the products often purchased. Brand loyalty is intrinsic commitment in repurchasing toward certain brands.

\section{Purchase Intention}

Purchase Intention is attitude available as response toward product or service. Purchase intention is also repurchase intention that shows consumer desires in order to repurchase (Wijaya, 2011).

According to Schiffman and Kanuk (2009), purchase intention is real thinking form, formed from several brands available in certain periods. Consumer purchase intention in doing transaction emerges because there is stimulus offered by company or seller. The stimulus can be designed for influencing purchase action. When purchasing, the consumer purchase intention is related to the desires owned for using or purchasing certain products.

\section{Conceptual Framework}

\section{CONCEPTUAL FRAMEWORK AND RESEARCH HYPOTHESIS}

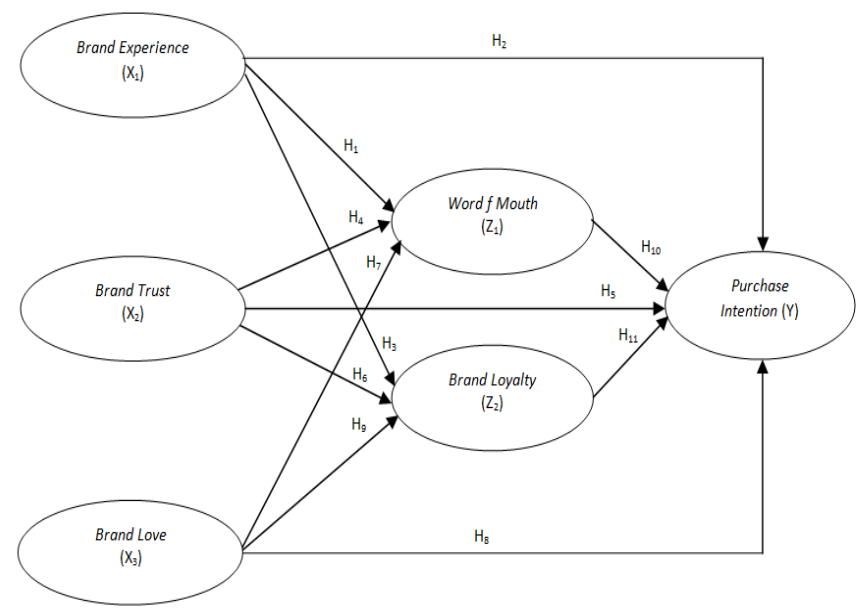

Picture 3.1 Conceptual Framework

\section{Research Design}

\section{RESEARCH METHODS}

The research design uses quantitative method. According to Sugiyono Sugiyono (2016) quantitative method is the research that uses research data such as numbers and the analysis uses statistics. The research type used is causal research. Causal research is the relation that characterizes cause and effect (Sugiyono, 2016).

\section{Population}

The population or generalization area is stated by the researcher in East Surabaya. The population taken in this research consists of users of Nike fashion branded.

\section{Samples}

Sample taking uses accidental sampling technique in which the method of determining samples is incidentally, whoever incidentally meets the researcher can be used as sample, if the person who is incidentally met, seen as suitable as sample (Sugiyono, 2016). These sample measures 
use sample measurement guide book according to Hair, et al. in Ferdinand (2011) that uses 5 to 10 times variable indicators. So, this research uses the samples of $5 \times 38=190$ respondents. The users of Nike brand fashion branded are 190 respondents, they are the samples taken in the research.

\section{Research Instrument}

Research instrument is used for measuring natural or social phenomena observed (Sugiyono, 2016). The intruments in this research use questionnaires that contain the answers related to the variables used in this research.

This research uses Likert scale in answering the questions in research questionnaires. So, the evaluational criteria use Likert scale that consists of 5 points, they are:

1. Very Disagreed (STS)

2. Disagreed (TS)

3. Quite Agreed (CS)

4. Agreed (S)

5. Agreed (SS)

\section{Data Analysis Technique}

Partial Least Square (PLS) is the analysis technique used. According to Ghozali (2016) for calculating, it uses the aid instrument of Smart Partial Least Square (PLS), because it has multi lane form and the model used has reflective form.

\section{Partial Least Square (PLS) Analysis \\ Outer Model Evaluation}

\section{Convergent Validity}

From the analysis results, it is seen that in all variable indicators, there is no variable indicator valid, in which the result has the value of loading factor $>0.50$, it means valid.

\section{Discriminant Validity}

Discriminant vaidity can be known through AVE method. The value of AVE has good discriminant validity because the value of AVE is $>0,5$. All construct variables are stated to have good discriminant validity.

\section{Composite Reliability}

The analysis results of all researh variables are $>0,70$. It shows that each variable has fulfilled composite reliability so it can be concluded that all variables are adequate in measuring the latent variables measured so they can be used in the further analysis.

\section{Cronbach Alpha}

From the value results of cronbach alpha, it is known that the value of cronbach alpha from all research variables is $>0,60$. Therefore, the results show that all research variables have fulfilled the value requirements of cronbach alpha, so it can be taken the conclusion that all variables have high reliability levels.

\section{Inner Model Test}

In this research, for testing the research hypothesis, it is used the analysis of Partial Least Square (PLS) by the program of Smart PLS. The following one is the PLS model picture submitted. 


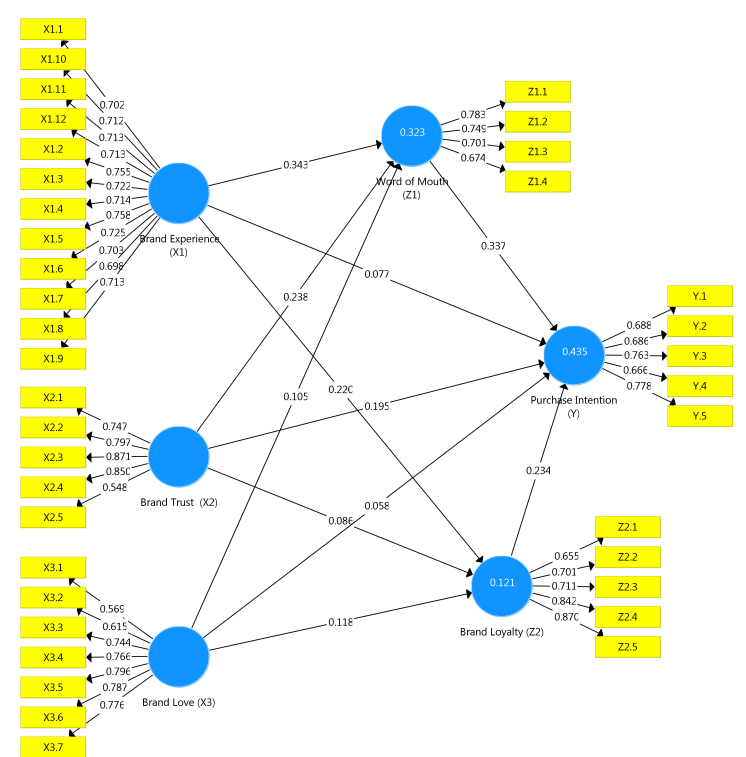

Picture 1. PLS Research Model

The inner weight value results of Picture 1 above show that the variables of Word of Mouth and Brand Loyalty are equally influenced by the variables of Brand Experience, Brand Trust, and Brand Love whereas the variables of Purchase Intention are influenced by Brand Experience, Brand Trust, Brand Love, Word of Mouth and Brand Loyalty explained in the structural similarities below this.

$\mathrm{Z}_{1}=0,343 \mathrm{X}_{1}+0,238 \mathrm{X}_{2}+0.105 \mathrm{X}_{3}$

$\mathrm{Z}_{2}=0.220 \mathrm{X}_{1}+0.086 \mathrm{X}_{2}+0.118 \mathrm{X}_{3}$

$Y=0.077 X_{1}+0.195 X_{2}+0.058 X_{3}+0.337 Z_{1}+0.234 Z_{2}$

\section{Hypothesis Testing}

T-statistic in Table 6 is for answering the research hypothesis as follows: 
Table 6. Hypothesis Testing Results

\begin{tabular}{|c|c|c|c|c|}
\hline & $\begin{array}{c}\text { Original } \\
\text { Sample (0) }\end{array}$ & $\begin{array}{c}\text { Sample } \\
\text { Mean (M) }\end{array}$ & (STDEV) & $\begin{array}{c}\text { T Statistics } \\
(\mid 0 / \text { STDEV } \mid)\end{array}$ \\
\hline $\begin{array}{l}\text { Brand Experience } \\
\left(\mathrm{X}_{1}\right)->\text { Word of } \\
\text { Mouth }\left(\mathrm{Z}_{1}\right)\end{array}$ & 0.343 & 0.342 & 0.094 & 3.631 \\
\hline $\begin{array}{l}\text { Brand Experience } \\
\left(\mathrm{X}_{1}\right) \text {-> Purchase } \\
\text { Intention }(\mathrm{Y})\end{array}$ & 0.077 & 0.076 & 0.077 & 1.001 \\
\hline $\begin{array}{l}\text { Brand Experience } \\
\left(\mathrm{X}_{1}\right)->\text { Brand } \\
\text { Loyalty }\left(\mathrm{Z}_{2}\right)\end{array}$ & 0.220 & 0.220 & 0.091 & 2.421 \\
\hline $\begin{array}{l}\text { Brand Trust }\left(\mathrm{X}_{2}\right)-> \\
\text { Word of Mouth }\left(\mathrm{Z}_{1}\right)\end{array}$ & 0.238 & 0.248 & 0.072 & 3.325 \\
\hline $\begin{array}{l}\text { Brand Trust }\left(\mathrm{X}_{2}\right)-> \\
\text { Purchase Intention } \\
\text { (Y) }\end{array}$ & 0.195 & 0.197 & 0.067 & 2.910 \\
\hline $\begin{array}{l}\text { Brand Trust }\left(\mathrm{X}_{2}\right)-> \\
\text { Brand Loyalty }\left(\mathrm{Z}_{2}\right)\end{array}$ & 0.086 & 0.097 & 0.090 & 0.952 \\
\hline $\begin{array}{l}\text { Brand Love }\left(\mathrm{X}_{3}\right)-> \\
\text { Word of Mouth }\left(\mathrm{Z}_{1}\right)\end{array}$ & 0.105 & 0.115 & 0.088 & 1.192 \\
\hline $\begin{array}{l}\text { Brand Love }\left(\mathrm{X}_{3}\right)-> \\
\text { Purchase Intention } \\
\text { (Y) }\end{array}$ & 0.058 & 0.065 & 0.073 & 0.793 \\
\hline $\begin{array}{l}\text { Brand Love }\left(\mathrm{X}_{3}\right) \text {-> } \\
\text { Brand Loyalty }\left(\mathrm{Z}_{2}\right)\end{array}$ & 0.118 & 0.126 & 0.085 & 1.377 \\
\hline $\begin{array}{l}\text { Word of Mouth }\left(\mathrm{Z}_{1}\right) \\
->\text { Purchase } \\
\text { Intention }(\mathrm{Y})\end{array}$ & 0.337 & 0.335 & 0.079 & 4.292 \\
\hline $\begin{array}{l}\text { Brand Loyalty }\left(\mathrm{Z}_{2}\right) \text { - } \\
>\text { Purchase } \\
\text { Intention }(\mathrm{Y})\end{array}$ & 0.234 & 0.232 & 0.064 & 3.652 \\
\hline
\end{tabular}

Source: Attachment 7

The testing results show that:

a. Brand Experience has significant influences toward Word of Mouth, in which the values of T statistic as 3.631 mean bigger than 1.96 .

b. Brand Experience does not have significant influences toward Purchase Intention, in which the values of T statistic as 1.001 mean smaller than 1.96.

c. Brand Experience has significant influences toward Brand Loyalty, in which the values of T statistic as 2.421 mean bigger than 1.96 .

d. Brand Trust has significant influences toward Word of Mouth, in which the values of T statistic as 3.325 mean bigger than 1.96 .

e. Brand Trust has significant influences toward Purchase Intention, in which the values of T statistic as 2.910 mean bigger than 1.96 .

f. Brand Trust does not have significant influences toward Brand Loyalty, in which the values of T statistic as 0.952 mean smaller than 1.96 .

g. Brand Love does not have significant influences toward Word of Mouth, in which the values of T statistic as 1.192 mean smaller than 1.96 .

h. Brand Love does not have significant influences toward Purchase Intention, in which the values of T statistic as 0.793 mean smaller than 1.96 .

i. Brand Love does not have significant influences toward Brand Loyalty, in which the values of T statistic 1.377 mean smaller than 1,96.

j. Word of Mouth has significant influences toward Purchase Intention, in which the values of T statistic as 4.292 mean bigger than 1.96 . 
k. Brand Loyalty has significant influences toward Purchase Intention, in which the values of T statistic as 3.652 mean bigger than 1.96 .

\section{Structural Model Testing (Inner Model)}

From PLS model, the results can be seen from the value of R-square for each dependent latent variable. R-square changes can be used for evaluating independent latent variable influences toward dependent latent variables whether having substantive influences. For endogenous latent variables in structural model that have the value of $\mathrm{R} 2$ as 0.75 , it indicates that model is strong, R2 as 0.50 indicates that model is moderate, R2 as 0.25 shows that model is weak. (Ghozali, 2016). PLS Outputs can be seen as explained as follows:

Table 7. Nilai $R$-Square

\begin{tabular}{|l|c|}
\hline & R Square \\
\hline Brand Experience $\left(\mathrm{X}_{1}\right)$ & \\
\hline Brand Trust $\left(\mathrm{X}_{2}\right)$ & \\
\hline Brand Love $\left(\mathrm{X}_{3}\right)$ & \\
\hline Word of Mouth $\left(\mathrm{Z}_{1}\right)$ & 0.323 \\
\hline Brand Loyalty $\left(\mathrm{Z}_{2}\right)$ & 0.121 \\
\hline Purchase Intention $(\mathrm{Y})$ & 0.435 \\
\hline
\end{tabular}

Source: Attachment 7

Based on the value testing results of R-square above, so it can be interpreted that:

1. Independent variables of Brand Experience, Brand Trust, and Brand Love that influence variables of Word of Mouth in structural model, have the $\mathrm{R}$ values as 0.323 that indicate that the model is weak.

2. Variables of Brand Experience, Brand Trust, and Brand Love that influence the variables of Brand Loyalty, have the R2 values as 0.121 that indicate that the model is weak.

3. Variables of Brand Experience, Brand Trust, Brand Love, Word of Mouth, and Brand Loyalty that influence the variables of Purchase Intention, have the R2 values as 0.435 that indicate that the model is weak.

The structural model suitabilities can be seen from $\mathrm{Q}^{2}$ as follows:

$\mathrm{Q}^{2}=1-[(1-\mathrm{R} 1) *(1-\mathrm{R} 2) *(1-\mathrm{R} 3)]$

$=1-[(1-0.323) *(1-0.121) *(1-0.435)]$

$=1-[(0.677) *(0.879) *(0.565)]$

$=1-[0.336]$

$=0.664$

The Q2 calculational results show that the Q2 values as 0.664 show that the Q2 values are strong. According to Ghozali (2014), the values of Q2 can be used for measuring how good are the observational values resulted by the model and also the parameter estimation. So, the prediction Q2 values conducted by the model are evaluated that they have had predictive relevance.

\section{DISCUSSIONS \\ Influences of Brand Experience Toward Word of Mouth}

Based on the research results, it is gotten that Brand Experience influences toward Word of Mouth in Fashion Branded in East Surabaya, because the values of T statistic as 3.631 mean bigger than 1.96. 
Brand experience is very important because company can create beautiful moments and they can be directly accepted by consumer so consumer will feel respected and capture good impressions from the company after doing purchase. Consumer who has done direct and indirect contacts toward some product, will emerge impressions personally through emotions that will determine consumer choices (Brakus et al, 2009).

The results in this research are proven that brand experience has significant and positive influences toward word of mouth. Positive influences that happen can be meant there are influences in the same directions between brand experience and word of mouth. This case can be meant that the better the experiences felt by consumer when consuming and purchasing products, so it will increase and increase consumer interests fore referencing products as some personal communications between purchaser and the people around him/her.

\section{Brand Experience Influences Toward Purchase Intention}

Based on the research results, it is gotten that Brand Experience does not influence significantly but it has positive direction influences toward Purchase Intention in Fashion Branded in East Surabaya, because the values of T statistic as 1.001 mean smaller than 1.96.

Purchase intention is consumer step in choosing among several brand choices, then finally doing purchases in the most favourite alternatives or processes passed by consumer for purchasing some products or services based on many considerations.

The research results are proven that brand experience does not influence significantly toward purchase intention but it has not negative influences. This case means that high consumer intention for purchasing can be formed through experiences felt by consumer when purchasing or consuming some products.

\section{Brand Experience Influences Toward Brand Loyalty}

Based on the research results, it is gotten the results that Brand Experience influences toward Brand Loyalty in Fashion Branded in East Surabaya, because the values of T statistic as 2.421 mean bigger than 1.96 .

The analysis results are proven that brand experience influences significantly toward brand loyalty by having positive influences. This case can be meant more clearly that the better the consumer experience formed through using some product or service, so it will increase consumer good attitudes toward some brand and have seriosity toward brand and have desires for forwarding the purchases in the future.

The results in this research support the findings of Pertiwi, Djawahir, and Andarwati (2017) who proved that there are direct significant influences in brand experience toward brand loyalty.

\section{Brand Trust Influences Toward Word of Mouth}

Based on the research results, it is gotten the results that Brand Trust influences toward Word of Mouth in Fashion Branded in East Surabaya, because the values of T statistic as 3.325 mean bigger than 1.96 .

Andriani and Bunga (2017) explained that brand trust is no doubt anymore as one of the strongest instruments for making relations between consumers and company as the most dominant marketing instruments. 
The analysis results in this research are proven that brand trust has significant and positive influences toward word of mouth so it can be concluded that high consumer trust toward brand can give contributions toward consumer for communications for exchanging informations such as giving recommendations personally or more toward some products or services.

\section{Brand Trust Influences Toward Purchase Intention}

Based on the research results, it is gotten the results that Brand Trust influences toward Purchase Intention in Fashion Branded in East Surabaya, because the values of $\mathrm{T}$ statistic as 2.910 mean bigger than 1.96 .

From the results achieved through this hypothesis testing, it is found that there are significant influences between brand trust and purchase intention by positive direction influences. This case can be meant that the higher the consumer trust toward some certain brand, so it will increase and increase consumer intention in purchasing some brand.

Purnamasari and Yulianto (2018) explained that trust feeling gotten from consumer emerges because of information that they seek from various websites in internet medias, further consumer will also conduct evaluational steps for determining purchase of some product.

The finding results of Wang \& dan Lee (2016) are parallel with the results in this results, that found that brand trust has significant influences toward purchase intention.

\section{Brand Trust Influences Toward Brand Loyalty}

Consumer love feelings toward some product also influence consumers indirectly in recommending the favourite brand toward other people. The attitude of recommending brand toward other people in this case is word of mouth. According to Sunyoto (2015) he stated that consumer will talk to other consumers about the experiences in using the products purchased, so advertisement through Word of Mouth characterizes as reference from other people.

Based on the research results, it is gotten that Brand Trust does not influence significantly but it has positive influences toward Brand Loyalty in Fashion Branded in East Surabaya, because the values of T statistic as 0.952 mean smaller than 1.96 .

Trust is the most important variable in developing long-term relations between one party and the other party. Kusuma (2014) said that consumer trust toward brand will impact on attitude loyalty or consumer attitude toward some brand. Loyalty in this case is brand loyalty.

The analysis results prove that brand trust does not have significant influences toward brand loyalty but it has positive influence directions. These positive influence directions can be meant that the higer the trust felt by consumer toward some certain brand, so it will increase and increase consumer loyalty toward the brand.

\section{Brand Love Influences Toward Word of Mouth}

Based on the research results, it is gotten the results that Brand Love does not influence significantly but it has positive influence directions toward Word of Mouth in Fashion Branded in East Surabaya, because the values of T statistic as 1.192 mean smaller than 1.96. 
Consumer love feelings toward some product also influence consumers indirectly in recommending the favourite brand toward other people. The attitude of recommending brand toward other people in this case is word of mouth. According to Sunyoto (2015) he stated that consumer will talk to other consumers about the experiences in using the products purchased, so advertisement through Word of Mouth characterizes as reference from other people.

These research results do not support the research results conducted by Borges et al (2016) who proved that brand love has significant influences toward WOM. These results are also not parallel with the research results of Fetscherin et al (2014) who found that there are positive and significant relations between brand love and WOM.

\section{Brand Love Influences Toward Purchase Intention}

Based on the research results, it is gotten the results that Brand Love does not influence significantly but it has positive influence directions toward Purchase Intention in Fashion Branded in East Surabaya, because the values of T statistic as 0.793 mean smaller than 1.96.

From the analysis results, it is achieved that brand love does not have significant influences toward purchase intention but it has positive or the same directions. The positive influences mean that the increasing the consumer love level toward some brand, so it can increase and increase consumer interest for purchasing also. So it can be said that high purchase intention can be formed through consumer love toward the brand.

Bargozzi, cs (2014) stated that brand love stimulates consumer repurchase intention. This case is parallel with the statement said by Borges et al (2016) who said that brand love has positive impacts toward purchase intention. The results in this research are not parallel with the research finding results of Fetscherin et al (2014) who proved that there are significant relations of brand love toward purchase intention but they are equally positive.

\section{Brand Love Influences Toward Brand Loyalty}

Based on the research results, it is gotten the results that Brand Love does not influence toward Brand Loyalty in Fashion Branded in East Surabaya, because the values of T statistic as 1.377 mean smaller than 1.96 .

Brand loyalty is consumer good attitude toward a brand, having seriosity toward the brand. Consumer good attitude toward some brand in this case is brand love.

The hypothesis testing results in this research are proven that brand love does not have significant influences toward brand loyalty, but in the research results are achieved that brand love has positive influences toward brand loyalty. It means that the higher the love feelings felt by consumers toward some brand, so it can increase and increase consumer loyalty toward some brand.

The research results are parallel with the research results conducted by Andriani and Bunga (2017) in which in their research was found that brand love does not influence toward brand loyalty.

\section{Word of Mouth Influences Toward Purchase Intention}

Based on the hypothesis testing results, it is achieved that word of mouth has significant influences toward purchase intention by positive influences. The positive influences can be said that there are the influences in the same directions between word of mouth and purchase intention that mean that the higer the communications from mouth to mouth by consumers for 
referencing some brand, so it will increase and increase consumer purchase intention. So high purchase intention can be formed by good word of mouth.

The research results are parallel with the research of Setyawan and Adiwijaya (2018) who found that Word of Mouth influences toward Purchase Intention. In which the results show that the better the words said by consumer toward other people about some products, so it will increase and increase consumer intention for purchasing.

\section{Brand Loyalty Influences Toward Purchase Intention}

Based on the research results, it is gotten the results that Brand Loyalty influences toward Purchase Intention in Fashion Branded in East Surabaya, because the values of T statistic as 3.652 mean bigger than 1.96 .

The analysis results prove that brand loyalty has significant and positive influences toward purchase intention. The positive influence directions can be meant that the more loyal the consumer attitudes toward some brand, so it will increase and increase consumer intention for purchasing toward some certain brand.

According to Andriani and Bunga (2017), brand loyalty can be defined as happy attitudes toward some brand represented in consistent purchases toward the brand all the time. In brand loyalty, there is no longer brand considered for purchased besides the product brand that is ofter purchased. Purchase Intention is attitude that emerges as response toward object. Purchase Intention is also repurchase intention that shows consumer will for repurchasing (Wijaya, 2011).

\section{CONCLUSIONS}

From the research results that have been conducted, so it can be taken the conclusions as follows:

1. Brand Experience influences toward Word of Mouth in Fashion Branded in East Surabaya.

2. Brand Experience does not influence significantly but having positive influence directions toward Purchase Intention in Fashion Branded in East Surabaya.

3. Brand Experience influences toward Brand Loyalty in Fashion Branded in East Java.

4. Brand Trust influences toward Word of Mouth in Fashion Branded in East Surabaya.

5. Brand Trust influences toward Purchase Intention in Fashion Branded in East Surabaya.

6. Brand Trust does not influence significantly but it has positive influences toward Brand Loyalty in Fashion Branded in East Surabaya.

7. Brand Love does not influence significantly but it has positive influence directions toward Word of Mouth in Fashion Branded in East Surabaya.

8. Brand Love does not influence significantly but it has positive influence directions toward Purchase Intention in Fashion Branded in East Surabaya.

9. Brand Love does not influence toward Brand Loyalty in Fashion Branded in East Surabaya.

10. Word of Mouth influences toward Purchase Intention in Fashion Branded in East Surabaya.

11. Brand Loyalty influences toward Purchase Intention in Fashion Branded in East Surabaya. 


\section{SUGGESTIONS}

From the analysis and discussions conducted, the suggestions submitted are as follows:

1. It is hoped that Nike Trademark can improve guaranteed qualities so it can be able to improve consumer trusts toward Nike trademark and it impacts on the increasing purchase interests also.

2. It is hoped that Nike Trademark can give strong impression toward consumer sense of sight as good trademark experience indication so it can drive consumers for referencing the trademark to other people as word of mouth form.

3. It is hoped that the next researchers who want to research thew same topics, in order to be able to use other variables that can influence purchase intention levels such as brand image, product quality, and price so it can improve the research results that have been achieved in this research.

\section{References}

Aboutalebi, S. S., and A. Kouloubandi. (2016). "The impact of the brand experience on Purchase Intentions (Case study West and Central branches of Tejarat Bank)". International Journal of Humanities and Cultural Studies (IJHCS) ISSN 2356-5926

Ali, Hasan. (2008). Marketing. Yogyakarta. Media Pressindo.

Andriani, M., dan F. D. Bunga (2017). "Faktor Pembentuk Brand Loyalty: Peran Self Concept Connection, Brand Love, Brand Trust Dan Brand Image". BENEFIT Jurnal Manajemen dan Bisnis. STIE Indonesia Banking School.

Assael, H. (2004). Consumer Behavior: A Strategic Approach, $6^{\text {th }}$ ed. Boston, MA: Houghton Mifflin Company. Assauri, S. (2013). Manajemen Pemasaran. Jakarta : Rajawali Pers.

Aydin, G., Aybeniz A. AR., Çağatan T. (2014). “The Role Of Brand Trust On Parents' Purchase Intentions Of BabyCare Products". Doğuş Üniversitesi Dergisi, 15 (2) : 165-180.

Bagozzi, R. P., Batra, R., \& Ahuvia, A. C. (2014). “Brand Love: Construct Validity, Managerial Utility, and New Conceptual Insights". Working paper. University of Michigan, Ann Arbor, MI

Bambang, B., Lubis, A. R., dan N. Darsono. (2017). "Pengaruh Brand Image, Brand Personality, Brand Experience Terhadap Brand Love Dampaknya Pada Brand Loyalty Gayo Aceh Coffee PT. Oro Kopi Gayo Kabupaten Aceh Tengah". Jurnal Perspektif Manajemen dan Perbankan. 8 (3) : 158- 184

Becerra, E. P., dan V. Badrinarayanan. (2013). "The influence of brand trust and brand identification on brand evangelism". Journal of Product \& Brand Management, 22 (5/6), 371-383.

Blackwell dan Paul W. Miniard., and Engel, James F., Roger D. (2008). Perilaku Konsumen, Jilid I, Jakarta : Bina Rupa Aksara

Borges, A. P., Cardoso, C., and R. Paula. (2016). "Consumer's love for functional brands: the Aspirin case". International Journal of Pharmaceutical and Healthcare Marketing 10 (4) : 477-491

Brakus, J. J., Schmitt,B.H., Zarantonello, L. (2009). "Brand Experience: What Is It? How Is It Measured? Does It Affect Loyalty?” Journal of Marketing research. 73 (3), pp. 52-68.

Carroll, B.A. and Ahuvia, A.C. (2006) “Some Antecedents and Outcomes of Brand Love”. Marketing Letters, 17, 7989.

Chaudhuri, A., \& Holbrook, M. B. (2001). "The chain of effects from brand trust and brand affect to brand performance: The role of brand loyalty". Journal of Marketing, 65(2), 81-93.

Chinomona, R. (2013). The Influence Of Brand Experience On Brand Satisfaction, Trust And Attachment In South Africa". International Business \& Economics Research Journal. 12 (10) : 1303-1316.

Ekaputri, A. H., Rahayu, A., dan L. A. Wibowo. (2016). "Pengaruh Brand Experience terhadap Kepuasan Pelanggan serta Dampaknya pada Repurchase Intention (Survei pada Pelanggan Klinik Skin Care di Kota Bandung)". Jurnal Ilmu Manajemen \& Bisnis. 7 (1) : 1-5

Ferdinand. A. (2011). Metode Penelitian Manajemen, Semarang: Indoprint.

Ferinda dewi, Erna. (2009). Market dan Psikologi Konsumen. Yogyakarta: Graha Ilmu.

Fetscherin, M., Boulanger, M., Gonçalves Filho, C., and Souki, G. (2014), "The Effect ofProduct Category on Consumer Brand Relationships", Journal of Product and Brand Management, 23 (2), pp. 78-89. 
Murtiningsih, T., Ridwan, M. S., \& Retnaningsih, W. (2019). Influences Of Brand Experience, Brand Trust, And Brand Love Toward Purchase Intention By Word Of Mouth And Brand Loyalty As Intervening Variables In Fashion Branded In East Surabaya. Archives of Business Research, 7(9), 106-120.

Ghozali, I. (2016). Aplikasi Analisis Multivariete Dengan Program IBM SPSS 23 (Edisi 8). Cetakan ke VIII. Semarang : Badan Penerbit Universitas Diponegoro

Goh Chin Wei (2014) "Factors Influencing Word Of Mouth Communication". Thesis. Master Of Science Management Universiti Utara Malaysia

Griffin, Ricky W. (2002). Manajemen Jilid 1 (Edisi 7). Edisi bahasa Indonesia. Jakarta : Erlangga.

Guna, R. A. (2014). "Pengaruh Brand Image Dan Brand Love Pada Word Of Mouth Smartphone Samsung Di Kota Padang”. Jurnal Universitas Andalas

Hamidun, M. A., dan B. Sanawiri. (2018). “Pengaruh Electronic Word Of Mouth Terhadap Purchase Intention Melalui Brand Image (Studi Pada Followers Akun Instagram @OUVALRESEARCH)”. Jurnal Administrasi Bisnis (JAB)|61 (2) : 61-68

Hardjanti, A. (2009). “Pengaruh Brand Competence, Credibility, dan Satisfaction terhadap Word of Mouth Bahavior melalui Trust". Media Riset Bisnis \& Manajemen. 9 (3)

Hasan, Ali. (2010). Marketing dari Mulut ke Mulut. Yogyakarta: Media Pressindo.

Hwang, J., and J. Kandampully, (2012) "The role of emotional aspects in younger consumer-brand relationships", Journal of Product \& Brand Management, 21 (2), pp.98-108

Indra, C. (2018). "Pengaruh Word of Mouth Terhadap Purchase Intention dengan Brand Image Dan Perceived Service Quality Sebagai Variabel Intervening Pada Program Kpr Bersubsidi Di Surabaya”. Jurnal Manajemen Pemasaran 12 (1) : 1-9

Ismail , A. R., \& Spinelli , G., (2012), "Effects of brand love, personality andimage on word of mouth The case of fashion brands among young consumers". Journal of Fashion Marketing and Management, 16 (4) : pp 504-518.

Khan, S. A., N. Ramzan., M. Shoaib., and A. Mohyuddin. (2015). "Impact Of Word Of Mouth On Consumer Purchase Intention". Sci. Int. (Lahore), 27 (1),479-482

Kotler P., and K. L. Keller. (2012). Marketing Management 14th edition. Jakarta : PT. Indeks Kelompok Gramedia. Kotler, P. (2012). Manajemen Pemasaran Jilid I. Diterjemahkan oleh Benyamin Molan. Jakarta: Indeks.

Kotler, P., and G. Armstrong. (2012). Prinsip-prinsip Pemasaran. Edisi. 13. Jilid 1. Jakarta : Erlangga.

Kuncoro. M. (2013). Mudah Memahami dan menganalisis Indikator ekonomi. Yogyakarta : UPP STIM YKPN.

Kusuma, Y. S. (2014). "Pengaruh brand experience terhadap brand loyalty melalui brand satisfaction dan brand trust Harley Davidson di Surabaya". Jurnal manajemen pemasaran. 2 (1):1-11

Lewarissa, Adrianus SN. 2012. "Pengaruh Brand Love Sebagai Faktor Mediasiantara Costumer Satisfaction terhadap Brand Loyality dan Positive WordOf Mouth Produk Notebook". Yogyakarta. Universitas Atma Jaya

Lovelock, Christopher \& Wirtz, Jochen. (2010). Services Marketing :People, Technology, Strategy, $7^{\text {th }}$ Edition. Pearson.

Mangara, A. K. H. (2013). “Analisis Pengaruh Brand Image Dan Word of Mouth (WOM) Terhadap Proses Keputusan Pembelian Handphone Blackberry". Skripsi. Universitas Negeri Yogyakarta.

Marist, A. I., L. N. Yuliati., and M. Najib. (2014). "The Role of Event in Building Brand Satisfaction, Trust and Loyalty of Isotonic Drink". International Journal of Marketing Studies 6 (6) : 57-65

McCarthy, E. J., Cannon, Joseph P., dan William D. Perreault. (2008). Pemasaran Dasar-pendekatan manajemen global. Jakarta: Salemba Empat.

Mohammadian, M. \& Karimpour, Y. (2014). "Identifying the Factors Influencing the Feeling of Love toward a Brand : The Adidas Case". Switzerland Research Park Journal,103 (1), 94-122.

Moreira, A. C., Fortes, N., dan R. Santiago. (2017). "Influence Of Sensory Stimuli On Brand Experience, Brand Equity And Purchase Intention". Journal of Business Economics and Management 18 (1) : 68-83

Muttaqiena, A. (2014, February 19). Menjelang IFW 2014, Industri Fashion Indonesia Tumbuh Pesat Retrieved September 9, 2016, from

www.seputarforex.com:http://www.seputarforex.com/saham/ekonomi/detail.php?id=160775dantitle=menjelan g_ifw_2014_industri_fashion_indonesia_tumbuh_pesat. 
Naufal, M. H., dan I. Maftukhah (2017) “Pengaruh Brand Image Dan Brand Love Terhadap Purchase Decision Melalui Word of Mouth". Management Analysis Journal 6 (4):377-387

Panjaitan, A. O. Y., Rofianty., dan Sudjatn. (2016). "Pengaruh Pengalaman Merek Terhadap Loyalitas Merek Melalui Mediasi Kepuasan Merek dan Kepercayaan Merek". Jurnal Bisnis dan Manajemen Vol. 3 No. 2, Juni 2016.

Pertiwi, A. R., A. H. Djawahir., and Andarwati. (2017). "Pengaruh Brand Experience Terhadap Brand Satisfaction, Brand Trust Dan Brand Loyalty". Jurnal Manajemen \& Kewirausahaan 5 (2) : 20 - 35 Management Department Faculty of Economics University of Merdeka Malang.

Peter, J Paul and Jerry C Olson. (2013). Perilaku Konsumen dan Strategi Pemasaran Terjemahan oleh Diah Tantri Dwiandani Edisi Kesembilan Jilid 1. Jakarta : Erlangga.

Pranadata, I. G. P., Rahayu, M., \& Hussein, A. S. (2017). Analisis Pengaruh Brand Experience Terhadap Brand Perceived Value, Brand Satisfaction dan Brand Loyalty (Studi Kasus pada Industri One Stop Carcare Service di Kota Malang). Jurnal Bisnis Dan Manajemen, 4(2), 217-227.

Purnamasari, D., dan E. Yulianto (2018) berjudul “Analisis Electronic Word Of Mouth Terhadap Keputusan Pembelian Produk Smartphone Oppo Dengan Brand Image Dan Brand Trust Sebagai Variabel Moderator (Survei pada konsumen Oppo Shop Center Sidoarjo)". Jurnal Administrasi Bisnis (JAB)| 54 (1) : 92-100.

Putra, S. W. (2016). “Pengaruh Kepercayaan Merek, Kesadaran Merek, Pengalaman Merek Terhadap Niat Beli Sepatu Futsal Adidas Di Surabaya”. Artikel Ilmiah. Sekolah Tinggi Ilmu Ekonomi Perbanas Surabaya.

Ratnawati, A., dan A. A. Lestari. (2018) "Peran Brand Trust Dalam Memediasi Brand Experience, Brand Personality Dan Brand Community Terhadap Brand Loyalty". EKOBIS 19 (2) : 185-202

Ridwan, MS and Marti, JV. 2012. The Study on Strategic Planning and Organizational Performance in the Regional Government Owned Banks in Indonesia. International Journal of Humanities and Applied Sciences (IJHAS) Vol. 1, No. 3.

Ridwan, MS. 2019. Strategy Development and Execution, and Feedback and Evaluation: The Indonesian Enterprises Evidence. Humanities and Social Sciences Reviews, Volume 7, No.3.

Ridwan, MS. 2017. Planning practices: A multiple case study in the high performing banks. Journal of Organizational Change Management, Volume 30, Nomer 4.

Ridwan, MS. 2016. Bumi, Lingkungan, dan Peradaban. Jurnal Doktor Ilmu Ekonomi, Volume 1, nomer 10ktober.

Rizan, M., Saidani, B., \& Sari, Y. (2017, April 8). “Pengaruh Brand Image Dan Brand Trust Terhadap Brand Loyalty Teh Botol Sosro Survei Konsumen Teh Botol Sosro di Food Court ITC Cempaka Mas, Jakarta timur". JRMSI - Jurnal Riset Manajemen Sains Indonesia, 3(1), 1-17.

Robbins, P.Stephen dan Timothy A. Judge. (2012). Perilaku Organisasi. Salemba. Empat. Jakarta.

Ruhamak, M. D., dan B. Rahayu. (2016). "Pengaruh Word Of Mouth Terhadap Purchase Intention Melalui Brand Image Pada Lembaga Kursus Bahasa Inggris Dynamic English Course Pare”. Jurnal Ekonomi Universitas Kadiri 1 (2) : 188-204

Saputra, D. (2016) “Pengaruh Electronic Word of Mouth dan Brand Image terhadap Purchase Intention Smartphone Apple iPhone di Bandar Lampung". Tesis. Program Pasca Sarjana Magister Manajemen Fakultas Ekonomi Dan Bisnis Universitas Lampung Bandar Lampung.

Satria, H. W., dan D. P. Hidayat. (2017) “Does Brand Love and Brand Image Have a Strong Impact on Word of Mouth? (Evidence from the Indonesian Vocational School)". in The $2^{\text {nd }}$ International Conference on Vocational Higher Education (ICVHE) "The Importance on Advancing Vocational Education to Meet Contemporary Labor Demands", KnE Social Sciences, pages 320-346.

Schiffman, Leon G dan Leslie Lazar kanuk. (2009). Perilaku Konsumen, Cetakan Keempat, dialih bahasakan oleh Zoekifli Kasip, Jakarta : PT. Macanan JayaCemerlang.

Semuel, H., dan A. S. Lianto. (2014) “Analisis eWom, Brand Image, Brand Trust Dan Minat Beli Produk Smartphone Di Surabaya". Jurnal Manajemen Pemasaran, 8 (2) : 47-54

Sernovitz, Andy. (2012). Word of Mouth Marketing: How Smart Companies get People Talking, New York. Penerbit: Kaplan Inc.

Setiadi, N.J. 2003. Perilaku Konsumen : Konsep dan Implikasi Untuk. Strategi dan Penelitian Pemasaran. Jakarta : Kencana.

Setyawan, J. L., dan M. Adiwijaya. (2018) "Pengaruh Brand Awareness, Brand Experience, Dan Word Of Mouth Terhadap Purchase Decision Pada Konsumen Baskhara Futsal Arena Surabaya". AGORA 6 (1) 
Sitorus, T., dan R. Hartono. (2017). "Efek Mediasi Custommer Trust Atas Pengaruh Word Of Mouth, Perceived Quality, Brand Image Terhadap Purchase Intention (Study empiris atas permintaan Personal Computer di wilayah Jakarta, tahun 2015)". Jurnal Magister Manajemen. 8 (2) : 58-91

Sugiyono. (2016). Metode Penelitian Kuantitatif, Kualitatif dan R\&D. Bandung: PT Alfabet.

Sunyoto, D. (2015). Manajemen dan Pengembangan Sumber Daya Manusia (Cetakan Pertama). Yogyakarta: CAPS (Center for Academic Publishing Service).

Swastha., D. B., dan Handoko, T. Hani. (2012). Manajemen Pemasaran. Analisis Perilaku Konsumen. Edisi Pertama. BPFE, Yogyakarta.

Tjiptono, Fandy. 2014. Pemasaran Jasa - Prinsip, Penerapan, dan Penelitian, Andi Offset, Yogyakarta.

Turgut, M. U., dan B. Gultekin. (2015). "The Critical Role of Brand Love In Clothing Brands”. Journal of Business, Economics \& Finance. 4 (1) : 126-152

Wang, Y. H., \& C. C. Lee. (2016) “Does Winning an Award Matter to Brand Trust and Purchase Intention?. Evidence from Franklin Templeton Investments". Journal of Business \& Economic Policy. 3 (1) : 75-81.

Widyastuti, S., Prasetyo, H., and I Gustari. (2017) "An Investigating on the Purchase Intention: Developing Dealers Reputation through Customer Trust and Service Quality". European Journal of Social Sciences 54 (3) : pp.316-331

Wijaya, I. M. (2011). The Influence Of Brand Image, Brand Personality And Brand Awareness On Consumer Purchase Intention Of Apple Smartphone. Jurnal Emba: Jurnal Riset Ekonomi, Manajemen, Bisnis Dan Akuntansi. 1 (4)

Yasin, M. \& A. Shamim (2013) "Brand Love: Mediating Role in Purchase Intentions and Word-of-Mouth". IOSR Journal of Business and Management (IOSR-JBM). 7 (2) : 101-109

Yulianti, I., dan W. Tung. (2013). "The Relationship among Brand Experience, Brand Image and Customer Satisfaction of Facebook Users in Indonesia". Proceedings Book of ICEFMO, 2013, Malaysia 